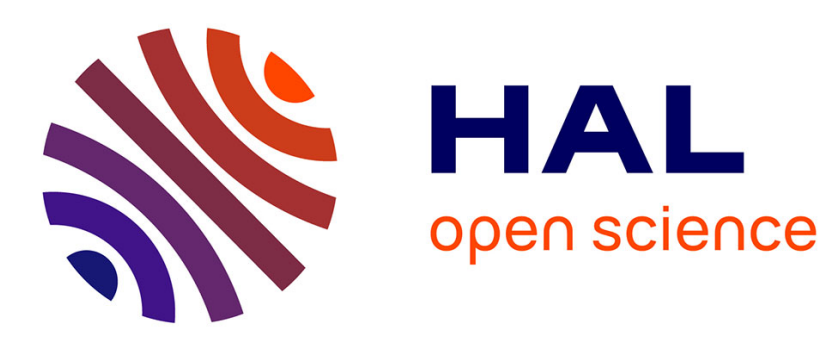

\title{
The neuroethology of olfactory sex communication in the honeybee Apis mellifera L.
}

\author{
Julia Mariette, Julie Carcaud, Jean-Christophe Sandoz
}

\section{To cite this version:}

Julia Mariette, Julie Carcaud, Jean-Christophe Sandoz. The neuroethology of olfactory sex communication in the honeybee Apis mellifera L.. Cell and Tissue Research, In press, 383 (1), pp.177-194. 10.1007/s00441-020-03401-8 . hal-03402732

HAL Id: hal-03402732

https://cnrs.hal.science/hal-03402732

Submitted on 25 Oct 2021

HAL is a multi-disciplinary open access archive for the deposit and dissemination of scientific research documents, whether they are published or not. The documents may come from teaching and research institutions in France or abroad, or from public or private research centers.
L'archive ouverte pluridisciplinaire HAL, est destinée au dépôt et à la diffusion de documents scientifiques de niveau recherche, publiés ou non, émanant des établissements d'enseignement et de recherche français ou étrangers, des laboratoires publics ou privés. 


\title{
The neuroethology of olfactory sex communication in the honeybee Apis mellifera L.
}

\author{
Julia Mariette $^{1}$ - Julie Carcaud ${ }^{1}$ - Jean-Christophe Sandoz ${ }^{1}$ (i) \\ Received: 15 October 2020 / Accepted: 14 December 2020 \\ (c) The Author(s), under exclusive licence to Springer-Verlag GmbH, DE part of Springer Nature 2021
}

\begin{abstract}
The honeybee Apis mellifera $\mathrm{L}$. is a crucial pollinator as well as a prominent scientific model organism, in particular for the neurobiological study of olfactory perception, learning, and memory. A wealth of information is indeed available about how the worker bee brain detects, processes, and learns about odorants. Comparatively, olfaction in males (the drones) and queens has received less attention, although they engage in a fascinating mating behavior that strongly relies on olfaction. Here, we present our current understanding of the molecules, cells, and circuits underlying bees' sexual communication. Mating in honeybees takes place at so-called drone congregation areas and places high in the air where thousands of drones gather and mate in dozens with virgin queens. One major queen-produced olfactory signal-9-ODA, the major component of the queen pheromone- - has been known for decades to attract the drones. Since then, some of the neural pathways responsible for the processing of this pheromone have been unraveled. However, olfactory receptor expression as well as brain neuroanatomical data point to the existence of three additional major pathways in the drone brain, hinting at the existence of 4 major odorant cues involved in honeybee mating. We discuss current evidence about additional not only queen- but also drone-produced pheromonal signals possibly involved in bees' sexual behavior. We also examine data revealing recent evolutionary changes in drone's olfactory system in the Apis genus. Lastly, we present promising research avenues for progressing in our understanding of the neural basis of bees mating behavior.
\end{abstract}

Keywords Insect · Sexual communication · Drone congregation · Olfaction · Antennal lobe $\cdot$ Macroglomerulus

\section{Introduction}

In addition to its well-known and crucial role as a pollinator and its enduring presence in our lives as a domesticated species, the western honeybee, Apis mellifera, has been for many years an influential model for the study of social insect behavior, genetics, sensory perception, as well as learning, memory and cognition (Winston 1987; Seeley 1995; Giurfa 2007; Menzel 2012; Zayed and Robinson 2012). In particular, due to the central role played by olfaction in this social insect's behavior, both inside the colony with a plethora of pheromones allowing them to communicate in numerous contexts and outside the colony for gathering resources, olfactory perception and learning have been intensively studied in honeybees (Galizia and Menzel 2000,

Jean-Christophe Sandoz

sandoz@egce.cnrs-gif.fr

1 Evolution, Genomes, Behaviour and Ecology, Université Paris-Saclay, CNRS, IRD, 91198 Gif-sur-Yvette, France
2001; Sandoz et al. 2007; Sandoz 2011; Giurfa and Sandoz 2012). Supported by extensive research on bees' olfactorymediated behaviors (e.g., Vareschi 1971; Laska et al. 1999; Guerrieri et al. 2005; Farina et al. 2007; Nouvian et al. 2015), this insect's olfactory pathways have been described in great details (e.g., Mobbs 1982; Rybak and Menzel 1993; Kirschner et al. 2006) and physiological recordings like electrophysiology (e.g., Abel et al. 2001; Brill et al. 2013; Strube-Bloss et al. 2016; Kropf and Rössler 2018) and optical imaging (e.g., Joerges et al. 1997; Sachse et al. 1999; Szyszka et al. 2005; Carcaud et al. 2012; Paoli et al. 2018; Jernigan et al. 2020) have unraveled some of the rules underlying odor coding. This important corpus of work has been almost exclusively performed on honeybee workers, the sterile members of the colony, and the behavior and sensory perception abilities of the sexuals, queens and drones, have received comparatively less scrutiny. Yet, honeybees possess one of the most fascinating mating behaviors displayed by insects with the formation of impressive drone congregations high in the air and the aerial ballet of drone comets following 
virgin queens. The sensory mechanisms underlying this remarkable behavior, which clearly involve olfaction as a central modality, have puzzled generations of scientists (Ruttner 1966, 1985; Gerig 1972; Koeniger and Koeniger 2004; Koeniger et al. 2014). As we will see, a key element of honeybee reproduction has been known for decades. It is indeed remarkable that the queen pheromone 9-oxo(E)-2decenoic acid (9-ODA) of the honeybee (Butler et al. 1959, 1962; Barbier and Lederer 1960), along with its nature as a sex attractant (Gary 1962), was discovered at approximately the same time as the first female moth pheromone, bombykol (Butenandt et al. 1959). Since then, enormous progress has been made in understanding moths' sex communication and how the olfactory system of the male moth is tuned to the detection of female pheromone components, from the periphery to higher-order brain centers (Kaissling 1987; Hildebrand 1996; Berg et al. 2014; Sakurai et al. 2014). In contrast, knowledge on sex communication and the neural basis of pheromone processing in honeybees has progressed more slowly, although in the last years, increasing evidence suggests that not only queens, but also drone pheromones are involved in this behavior (Brandstaetter et al. 2014; Bastin et al. 2017a, 2017b; Villar et al. 2017). In this article, we aim to prompt new efforts at unraveling the neural basis of honeybee mating, by reviewing what we know of this behavior, the sensory cues involved, as well as the molecules, cells, and circuits underlying it. We also present what we perceive as the most promising research avenues.

\section{The actors-queens and drones}

The honeybee colony houses three types of individuals: a queen, the colony's only reproductive female, a few tens of thousands of sterile worker females, and a few hundred males, produced only during the breeding season (Winston 1987; Page Jr and Peng 2001). While workers carry out the majority of the colony tasks such as foraging, hive defense, brood care, queen care, and cleaning, the queen is in charge of the production of new individuals and influences the physiology and behavior of the whole colony through her pheromones (Winston 1987; Seeley 1995). Males do not participate in colony tasks and are specialized in reproduction. We will describe in more details queens and drones.

\section{The queen}

Originating from diploid eggs, queens are female bees, which receive royal jelly during their whole development, while workers only receive royal jelly during the first larval days (Weaver 1966; Maleszka 2018). Compared with workers, their developmental time is shorter
(16 days compared with 21) and they develop a set of specific morphological features: a longer abdomen, different mouthparts, no pollen-collecting structures on the legs among others (Michener 1974; Winston 1987). Virgin honeybee queens become sexually mature around the age of 7 days after emergence and usually start leaving the hive for orientation flights and then nuptial flights around that time. These mature queens present complete functional genital organs, with very large ovaries that can produce more than one million eggs in her lifetime. Their spermatheca can be filled with 5 million spermatozoa, which are collected during one, sometimes two, mating flight(s) (Koeniger et al. 2014). Spermatozoa remain viable during the queen's lifetime, and thus, after mating, the queen will not leave the hive anymore except for swarming when the colony becomes too populous (Simpson 1958; Rangel and Seeley 2012).

\section{The drone}

Drones develop from unfertilized eggs and are therefore haploid. Queens produce drones when the pollen status of the colony, the principal source of proteins, is optimal (Free and Williams 1975; Smith et al. 2015). Drones' morphology is highly distinguishable from workers. They do not take part in the colony's tasks and do not possess any of workers' anatomical tools such as a sting apparatus, pollen baskets, a long proboscis, or strong mandibles (Winston 1987). Drone's anatomy is on the contrary optimized for mating and flight performance with highly developed wing muscles and an enlarged thorax. Drones also display enlarged eyes, with more than 8000 ommatidia compared with less than 6000 in workers and between 3000 and 4000 in queens, helping them to orientate faster during flights and to spot queens efficiently during mating (Dade 1977; Gries and Koeniger 1996). Sexual dimorphism is also present in the olfactory system, a subject addressed in more details below.

\section{The stage-drone congregation areas}

Reproduction starts with thousands of drones leaving the hives on sunny summer afternoons. When they get about 7-9 days old, the drones become sexually mature and start to perform short defecation and orientation flights around the hive. A short time later, they start leaving the hive for longer durations ( $>25 \mathrm{~min}$ ) in order to mate (Howell and Usinger 1933; Ruttner 1966; Witherell 1971; Koeniger et al. 2014). Drones only leave for mating flights at particular times of the day (early afternoon) and only when they detect appropriate weather conditions, typically warm sunny weather without too much wind 
(Currie 1987). The perception mechanisms involved in the detection of these specific conditions by drones are still unknown. Drones perform an average of 2-4 flights per day and fly up to $7 \mathrm{~km}$ from their hive for mating (Ruttner and Ruttner 1972; Currie 1987). They gather in thousands at particular locations, high in the air (10-40 $\mathrm{m}$ from the ground) and form a so-called congregation, where they remain flying in wide loops, until they return to the colony to feed themselves (Ruttner 1966). Drone congregation may contain at any one time as many as 11,000 drones from up to 240 different colonies, ensuring panmixis (Free 1987; Baudry et al. 1998; Koeniger et al. 2005). Then, about $1 \mathrm{~h}$ after the peak of drones' departure, virgin queens leave the hive and join the drone congregations (Ruttner and Ruttner 1965, 1966; Koeniger and Koeniger 2004). As soon as a virgin queen enters the congregation and drones have detected her, they form a comet-like swarm behind her and engage in a scramble competition trying to find the best position for mating (Gries and Koeniger 1996). Congregations have a limited spatial extension, with a diameter between 30 and $200 \mathrm{~m}$. Copulations only take place within the congregation, and if a virgin queen leaves outside the virtual borders of the congregation, drones are no longer attracted by her (Ruttner and Ruttner 1966). When the fastest drone has clasped the queen, he instantly transfers his endophallus into the wide-open sting chamber of the queen. Within 15-30 min, the queen mates with 10-20 drones which die directly after copulation (Woyke 1955; Baudry et al. 1998; Schlüns et al. 2005). This polyandrous copulation with males originating from a wide range of different colonies gives rise to as many patrilines among the queen's offspring, which is beneficial to the colony in terms of physiological and behavioral diversity of its members (Estoup et al. 1994; Jones et al. 2004; Junca et al. 2019). After one or a few nuptial flights, when her spermatheca is full, the queen returns to the colony (Schlüns et al. 2005). After a delay of about one week, she will start laying eggs for the rest of her life.

\section{Sensory cues involved in honeybee mating}

\section{Visual cues}

Because of the low accessibility of drone congregations located high in the air, the search for the cues used by drones and virgin queens to find them has been difficult, even though it started more than a century ago (Sladen 1901, 1902 in Free 1987 and Koeniger et al. 2014). The formation of the congregations entirely depends on the drones and is independent of the queens' presence, which join the congregations about $1 \mathrm{~h}$ after the drones (Ruttner and Ruttner 1966; Koeniger and Koeniger 2004). The location of drone congregations is surprisingly constant from year to year, and some congregations have been reported to form consistently at the same place over decades (Ruttner 1966; Ruttner and Ruttner 1968; Page Jr and Peng 2001; Rueppell et al. 2005). This is especially remarkable since drones' life span is limited to a few weeks (Ohtani and Fukuda 1977) and communication of these locations from 1 year to the next is therefore out of question. Consequently, sensory cues must exist that lead the drones to these specific locations every year. When they leave the hives, orientation of the drones is thought to depend mainly on visual cues. They are for instance spontaneously attracted to "depletions on the horizon," areas of maximum light intensity, like valleys (Fig. 1) (Koeniger et al. 2014). When they reach a more even light distribution, they would tend to fly around and reorientate. Also, when flying, the drones tend to follow certain flight routes called flyways and in particular they follow tree lines (Loper 1992). It has been suggested that drone congregation areas would often appear at the end or at intersections of such drone flyways. At such branch points, drones would also reorient by flying higher to find additional cues (see below). Visual cues also play an important role when a queen enters the congregation, and the drones use her contrasted shape against the sky to reorient quickly towards her (Koeniger et al. 2014). Drones are known to follow any similar-sized object, like a small stone, for a short distance if it crossed the congregation (Ruttner 1985). In addition to visual cues, anomalies in the terrestrial magnetic field have also been proposed to play a role in the localization of drone congregations at particular locations, but until now definite proof is lacking (Loper 1985).

\section{Olfactory cues}

Both the formation of drone congregations and the pursuit of the queen by drones depend on olfactory cues. It is this second point that first attracted attention of the research community. At the end of the 1950s, approximately at the same time, two teams in France and the UK isolated the major component of the queen mandibular pheromone: 9-oxo-(E)-2-decenoic acid (9-ODA) (Butler et al. 1959; Barbier and Lederer 1960). The queen mandibular pheromone (QMP) is notably composed of five components produced by the mandibular glands: 9-ODA, two enantiomers $(R)$ - and $(S)$-9-hydroxy- $(E)$-2decenoic acid (9-HDA), $p$-hydroxybenzoate (HOB), and 4-hydroxy-3-methyoxyphenylethanol (HVA) (Slessor et al. 1988). The QMP plays a crucial role in maintaining the colony cohesion, through primer effects inhibiting workers' ovary development as well as releaser effects inducing notably the retinue behavior of workers towards 


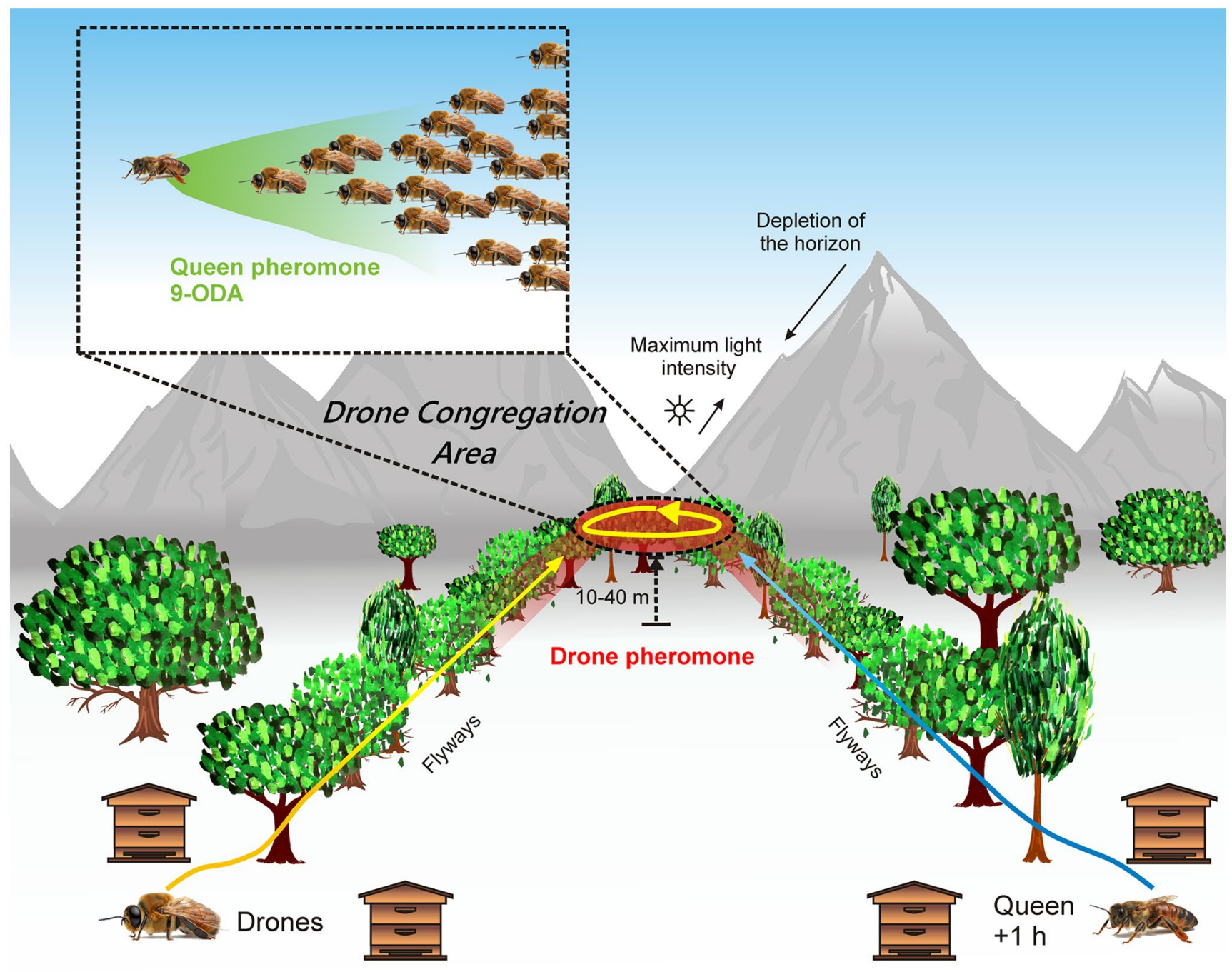

Fig. 1 Honeybee mating behavior and the involved sensory cues. Drones leave their colonies on warm summer afternoons, and spontaneously fly in the direction of depletions on the horizon (valleys for instance), attracted by high light intensity. When flying, they tend to follow particular flyways, for instance, along tree lines (yellow arrow). At areas of more even light distribution and/or at intersection of flyways, drones reorient, flying in wide loops, and accumulate around $10-40 \mathrm{~m}$ in the air. A putative drone pheromone (red) produced in higher amount in this area would accelerate the attraction

the queen (Butler and Fairey 1964; Free 1987; Slessor et al. 1988, 2005). In addition to these social effects, 9-ODA was shown to be attractive for drones under natural outdoor conditions (Gary 1962; Brockmann et al. 2006), as well as on a treadmill under laboratory conditions (Brandstaetter et al. 2014). The proportion of 9-ODA within the QMP (relative to the other components cited above) differs depending on queens' mating status, with a higher proportion in virgin queens compared with mated queen (Pankiw et al. 1996; Rhodes and Lacey 2007; Strauss et al. 2008). Accordingly, in free-flying of other drones and stabilize the congregation at this location. Leaving the hives about $1 \mathrm{~h}$ after the drones, virgin queens are thought to use, like the drones, both visual and olfactory cues to join the congregation (blue arrow). As soon as she enters the congregation limits (see inset), thanks to her sex pheromone 9-ODA (green), the queen is followed by a comet of drones attempting to approach her and mate. After mating with 12-20 drones, the queen will return to her colony and start laying eggs after a delay of 1 week, for the rest of her life

attraction assays, the QMP of virgin queens is much more attractive than that of mated queens (Villar et al. 2019), a result that fits with the observation that the QMP of a mated queen is not attractive on a treadmill contrary to 9-ODA (Brandstaetter et al. 2014). Interestingly, the amount of 9-ODA in the QMP is also influenced by a temporal factor: virgin queens produce higher amount of 9-ODA between 11 am and 5 pm daily, roughly the period during which mating flights take place (Pain and Roger 1978). All these elements concur to conclude that QMP, with its varying amount of 9-ODA, appears to be 
a reliable signal for the sexual maturity and readiness of virgin queens (Villar et al. 2019). To summarize, 9-ODA is clearly responsible for drones' attraction toward queens within the congregation. Together with visual cues of the queen, it results in the formation of a comet composed by pursuing drones. The role of other QMP components is controversial, and some may play a facilitating role when present in a blend with 9-ODA. In particular, one study found drone attraction to 9-HDA (Butler and Fairey 1964) but two subsequent studies failed to reproduce this result (Blum et al. 1971; Boch et al. 1975). In a more recent study, drone attraction at a short range (i.e., drones making contact with a dummy) was improved when 9-HDA and 10-HDA were added to 9-ODA (Brockmann et al. 2006). Lastly, evidence also points to a possible short-range effect of tergal gland secretions, possibly in synergy with 9-ODA and/or visual cues (Vierling and Renner 1977; Villar et al. 2019). Clearly, there may be gaps in our knowledge of queenemitted sexual pheromones.

As mentioned above, the formation of the congregation is independent of the queens' presence and the current hypothesis is that olfactory cues are involved in the formation and the maintenance of the congregation. For instance, visual cues alone cannot explain the clear-cut dimensions of a drone congregation: when a virgin queen leaves the congregation, drones rapidly stop their pursuit and return to their consexuals within the congregation (Ruttner and Ruttner 1965; Ruttner 1985; Loper et al. 1992). The idea of drone-emitted volatiles has been put forward more than a century ago. In 1902, Sladen already wrote: "it is clear that the scent of the queen attracted the drones and it seems to me likely that the ardent drones attracted the other drones by emitting a scent themselves" (in Free 1987). Since that time, the existence of a drone pheromone has been repeatedly evoked but it has not been identified yet (Gerig 1972; Lensky et al. 1985; Free 1987; Brandstaetter et al. 2014; Bastin et al. 2017a, 2017b; Villar et al. 2017). Flying drones were shown to be attracted to drone extracts, and more strongly to head than to thorax or abdomen extracts (Gerig 1972). Later, this idea was confirmed and flying drones were found to be attracted to drone mandibular gland extracts (Lensky et al. 1985). On a treadmill under laboratory conditions, drones' attraction could be observed toward the volatiles emitted by a group of live drones (Brandstaetter et al. 2014). This drone inter-attraction is age-dependent, with significant attraction between 12- and 15-day-old drones, when the drones are sexually mature and leave for mating flights, but not between younger, immature, drones (Bastin et al. 2017b). Indeed, the composition of drones' volatile emissions changes with age (Bastin et al. 2017b). These results are compatible with a possible role of mandibular gland secretions. Although drones' mandibular glands are very small compared with those of queens and workers, the structure of the drone glands varies during the first 15 days of adult life, swelling until about 9 days, and then starting to degenerate (Lensky et al. 1985). Accumulated gland product appears to be stored in the gland lumen and is possibly liberated later during mating flights. Honeybee drone mandibular glands produce saturated, unsaturated, and methyl branched fatty acids, with two major components: hexadecanoic acid and (Z)-9octadecanoic acid (Villar et al. 2017). Natural extracts of drones mandibular glands as well as a synthetic blend of the six major components were both found to be attractive for drones when disposed on flyways (Villar et al. 2017). All these elements suggest that drone-emitted volatiles contribute to the formation of drone congregations, possibly in a two-step process: first by accelerating drone aggregation and then by stabilizing the drone cloud. These drone cues may also be used by the virgin queens to find the congregations. It was actually demonstrated that virgin queens but not workers of the same age are attracted towards drone-emitted volatiles on a treadmill (Bastin et al. 2017a).

\section{The honeybee olfactory system and its sex/ caste dimorphism}

The honeybee olfactory system presents a strong caste and sex dimorphism, drones' and queens' olfactory systems differing from workers' olfactory system both anatomically and functionally, as they are adapted to different, and probably less diversified behavioral tasks, than workers (Fig. 2). We will describe the specificities of each sex while progressing along the olfactory pathway.

\section{The periphery}

Odorants are detected at the level of honeybees' antennae, where there is already a high sexual dimorphism between males and females. Drones' antennae are anatomically different, with a larger size and one more segment on the flagellum than in workers (11 vs 10 ), so that the antenna surface is about twice that of the worker (Lacher 1964; Esslen and Kaissling 1976; Kropf et al. 2014). Odorants enter in contact with the olfactory system at the level of specialized structures on the antenna surface, the sensilla, which enclose the dendrites of olfactory sensory neurons (OSNs). Honeybees present about 10 different types of sensilla with varying morphologies on their antennae (Lacher 1964; Esslen and Kaissling 1976). Three of them have been classified as olfactory sensilla: S. basiconica, S. trichodea (type A), and S. placodea. The last type, also 


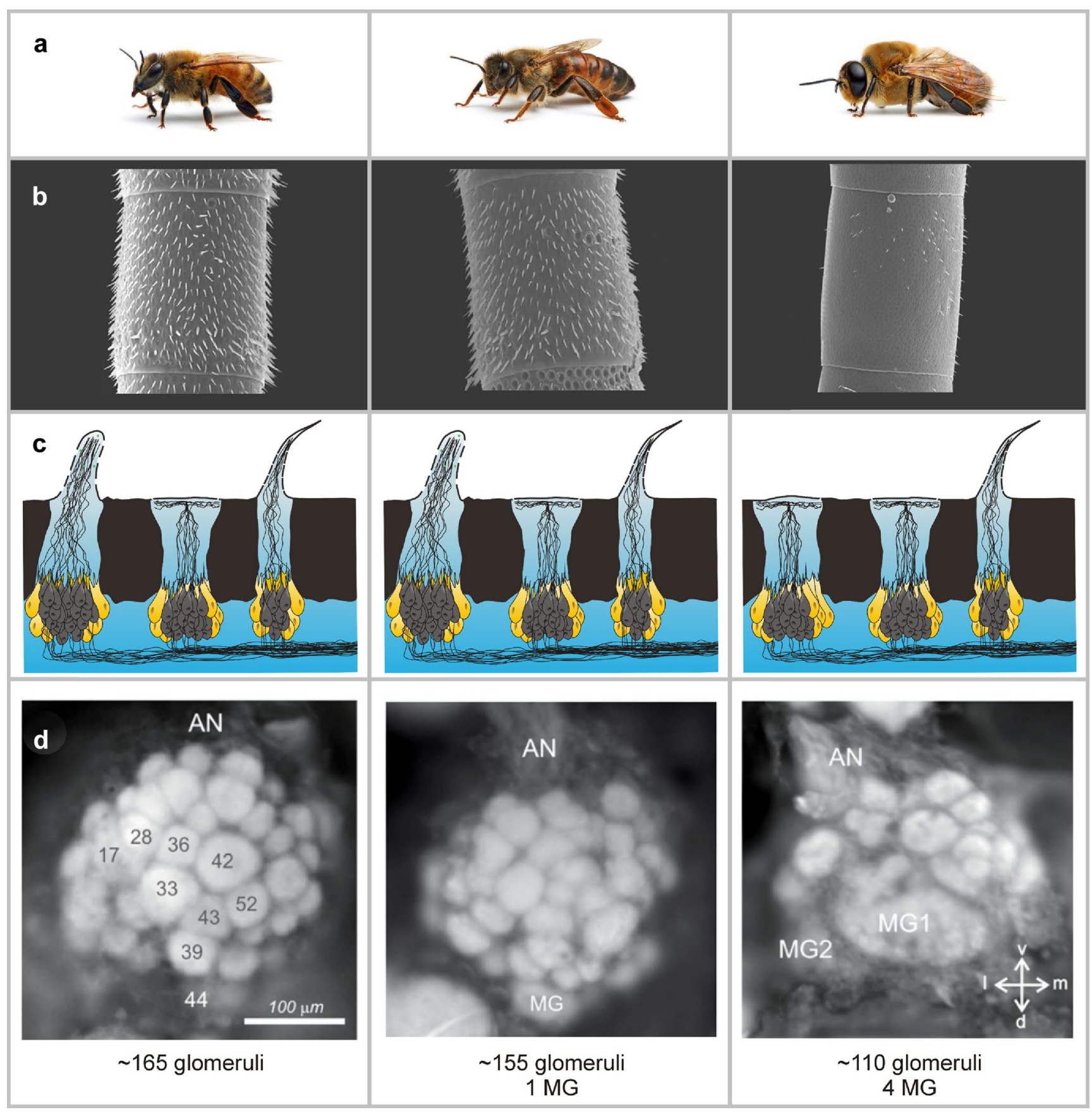

Fig. 2 Caste and sexual dimorphism of honeybee's olfactory system. a From left to right: honeybee worker, queen, drone. b, c The drone antenna presents 11 segments on the flagellum, compared with 10 in both workers and queens. The pictures show one such segment in the three hive members. Sensory equipment on the antenna is highly dimorphic between males and females. Contrary to workers and queens which possess 3 types of olfactory sensilla (from left to right $S$. basiconica, S. placodea, and S. trichodea type A), drones have only 2 types, with a much higher number of $S$. placodea than females and a lower number of $S$. trichodea. Queens present a lower number of $S$. placodea than workers. d The antennal lobe, first processing stage of the olfactory pathway. Workers possess $\sim 165$ isomorphic glomeruli. Queens' AL has a slightly lower number of isomorphic glomeruli and 1 enlarged glomerulus (macroglomerulus, MG). Drones have less glomeruli than females ( 110) but 4 strongly enlarged units (MG1-4), two of which are visible on this image. Honeybee pictures in a by Alex Wild; antenna electronic microscopy pictures in b from Fang et al. (2012); antennal lobe pictures in d from Sandoz et al. (2007) 
called placode sensilla, are the more numerous and cover large regions of the honeybee antenna (Slifer and Sekhon 1961; Esslen and Kaissling 1976). Electrophysiological recordings showed that they respond to a wide range of olfactory stimuli including floral odorants, social pheromones, as well as sex pheromone compounds in drones (Lacher 1964; Vareschi 1971; Esslen and Kaissling 1976; Getz and Akers 1993). Following the antenna size difference mentioned above, an important dimorphism is found in terms of absolute number of placode sensilla on the antenna: while the worker antenna contains about 2200-2700 placodes, drones harbor more 15,000-18,000 of them (Esslen and Kaissling 1976; Brockmann and Brückner 2005; Fang et al. 2012). Considering the twice larger surface of the drone antenna, this still translates in a densification of placode sensilla in the drone, with a twofold higher density compared with workers (Esslen and Kaissling 1976). At the same time, other sensillum types (S. trichodea type A) are reduced in number or even utterly disappear in the drone (S. basiconica). Contrary to the case of the drone, queens are thought to possess a lower number of placodes than workers, around 1600 (Snodgrass 1956; Ribbands 1953; Fang et al. 2012). Each placode houses 10-30 OSNs (Lacher 1964; Schneider and Steinbrecht 1968; Esslen and Kaissling 1976). Accordingly, while the worker antenna contains 65,000-100,000 OSNs, depending on the studies, that of the drone is thought to harbor 280,000-340,000 OSNs (Esslen and Kaissling 1976; Brockmann and Brückner 2001; Streinzer et al. 2013). This dimorphism is even more evident concerning placodes housing OSNs tuned to 9-ODA, which abound in drones as suggested by electrophysiological recordings (Kaissling and Renner 1968; Vareschi 1971). This is also confirmed by electroantennogram recordings of the whole antenna, which showed that drones' antennae are more sensitive and responsive to 9-ODA than workers' (Vetter and Visscher 1997; Brockmann et al. 1998; Brockmann et al. 1998). The drone olfactory system, like that of workers, undergoes a maturation process that continues during the first days after adult emergence (Masson et al. 1993). The electrophysiological responses of drone antennae (electroantennogram, henceforth EAG) to queen volatiles were measured at different ages with apparently conflicting results. While Skirkeviciene and Skirkevicius (1994) observed a steady increase in EAGs to a queen extract in the first 8 days of a drone's life, Vetter and Visscher (1997) described a general decrease of EAGs in the course of 40 days (an old age for drones), and Villar et al. (2015) found lower responses to 9-ODA at 14 days than at 4 days. These observations suggest that the sensitivity of the drone antenna increases in the first days after emergence and shows a plateau around 8 days but undergoes a slow decrease after that.

\section{Olfactory receptors}

Odorant molecules reach OSN dendrites by diffusing through an extracellular fluid, the sensillum lymph, filling the sensillum cavity (Kaissling 1987; Masson and Mustaparta 1990). In this fluid, a number of associated proteins participate in olfactory transduction, including odorant binding proteins (OBPs) which are thought to help transport hydrophobic odorants to the OSN membrane (Danty et al. 1997, 1998, 1999; Vogt 2003; Pesenti et al. 2008). The role of OBPs is still controversial, and they do not seem to be always essential, as shown in Drosophila in which OSNs' responses were found to be conserved in multi-OBP mutants (Xu et al. 2005; Xiao et al. 2019). Compared with other insects such as fruit flies, which possess 52 OBPs, honeybees possess few OBPs, in total about 21 (Foret and Maleszka 2006; Vieira and Rozas 2011). One of them, called ASP1, was identified early as a potential 9-ODA binding protein (Danty et al. 1999; Pesenti et al. 2008).

ORs are 7-transmembrane domain receptors specific to insects, probably having evolved from gustatory receptors in a common ancestor of winged insects (Missbach et al. 2014). Insect ORs form heteromeric complexes with a unique and obligate co-receptor named Orco (Larsson et al. 2004; Benton et al. 2006). These complexes form ligand-gated non-selective cation channels that can open directly upon activation by an appropriate ligand (Sato et al. 2008; Wicher et al. 2008; Butterwick et al. 2018). In general, each OSN expresses only a single OR gene together with Orco, and the functional properties of the OR are thus responsible for the response spectrum of the OSN. ORs are highly divergent both within a species and between species, and unique lineage-specific expansions of OR clades have been observed in the different insect orders (Hansson and Stensmyr 2011). The honeybee genome contains about 170 functional OR genes (Robertson and Wanner 2006; Karpe et al. 2016; Jain and Brockmann 2020). Interestingly, the honeybee genome presents several bee-specific expansions of the OR repertoire presumably underlying their remarkable olfactory abilities in both social and food-gathering contexts (Robertson and Wanner 2006). Transcriptomic analyses of honeybee antennae demonstrated very significant biases in OR gene expression between workers and drones (Wanner et al. 2007; Jain and Brockmann 2020). The most recent study identified a set of 24 genes that were significantly more strongly expressed in drones, while 67 OR genes were more strongly expressed in workers (Jain and Brockmann 2020). These expression biases are more or less marked,but in the drone 4 OR genes stand out as the most strongly overexpressed in twoindependent studies: AmOR10, -11, -18, -170 


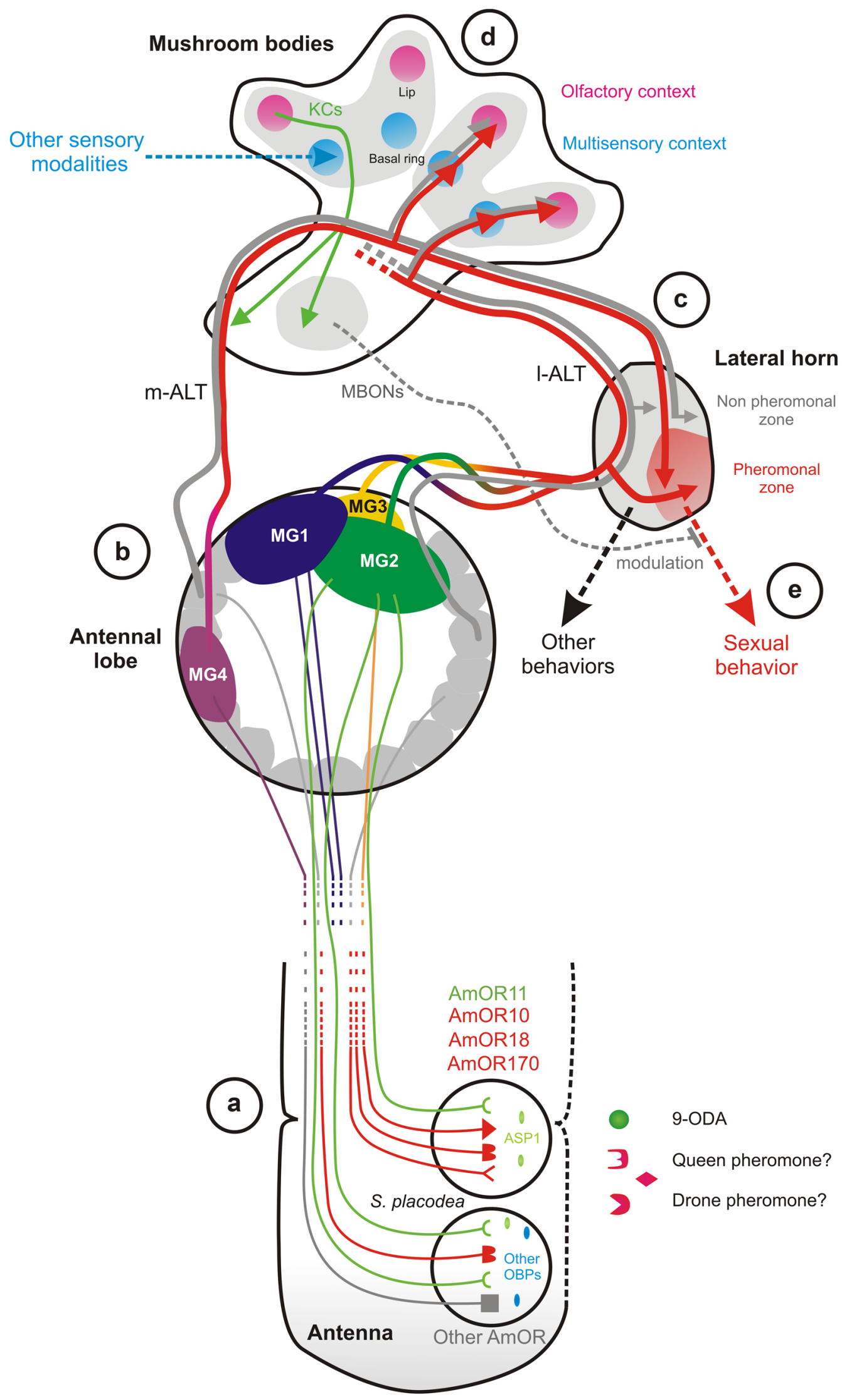


4Fig. 3 Working model of olfactory circuits involved in honeybee drones' mating behavior The figure shows olfactory pathways on one brain hemisphere. a The placode sensilla of the drone antenna contain olfactory sensory neurons (OSNs) carrying olfactory receptors tuned to mating pheromones (red), in particular AmOR11 tuned to the queen pheromone compound 9-ODA (green). Odorant-binding proteins (OBPs) like ASP1 are thought to participate in the transport of odorants to the receptor. Placodes typically contain 10-30 OSNs and probably include both pheromone-responsive and non-pheromone responsive OSNs; b all OSNs carrying the same OR type project to the same glomerulus in the antennal lobe (AL). The drone AL contains $\sim 110$ glomeruli, among which 4 enlarged units, the macroglomeruli MG1-MG4. MG2 is known to respond to 9-ODA and probably gathers all OSNs carrying AmOR11; it is suspected that OSNs carrying the 3 other drone over-expressed ORs project to MG1, MG3 and MG4. After processing by local interneurons, second-order neurons, the projection neurons (PNs), convey AL information towards higher-order centers, the lateral horn and mushroom bodies. The honeybee brain contains two main uniglomerular PN pathways: the 1-ALT conveying information from MG1-3 and the m-ALT conveying information from MG4. c The lateral horn is a premotor center organizing innate behavior. PNs are believed to project to segregated LH areas depending on odorants' biological value. PNs from the MGs would thus project to a sexual behavior dedicated area, possibly subdivided depending on each MG's function. $\mathbf{d}$ The mushroom bodies are a center for multisensory integration, learning and memory, in which PN inputs are combinatorially rearranged onto highly specific intrinsic neurons, the Kenyon cells (KCs). Possibly here, integration of multiple odorants, for instance, queen pheromones with drone pheromone or sex pheromones with environmental odorants, takes place (KCs with dendrites in the calyx lip). In addition, integration of olfactory information with other modalities (vision, mechanosensory, etc.) could also take place here (KCs with dendrites in the calyx basal ring). e Mushroom body output neurons (MBONs) could relay contextualized and multimodal information to the lateral horn, possibly modulating pre-motor output from the lateral horn

(Wanneret al., 2007; Jain \& Brockmann, 2020). As the only acknowledged role of the drones is reproduction, the four overexpressed olfactory receptors are suspected to play a role in the mating process, by participating in the detection of sexual pheromones. This hypothesis was confirmed when AmOR11 was expressed, together with AmOrco, in a heterologous system, the Xenopus oocyte. In these conditions, a functional OR was formed, which showed a high affinity for 9-ODA (Wanner et al. 2007). This study also confirmed the necessary role of AmOrco for OR activation in bees, as without its co-expression, no responses were obtained in this system. Although in this initial study the other three drone-overexpressed receptors were also studied, none of the known queen pheromone components activated them, leaving the question of their exact function open (Wanner et al. 2007). OR expression is not only sexually dimorphic between sexes, but it also changes with age. In particular, AmOR11 was shown to be more strongly expressed in mature drones than in immature drones (Villar et al. 2015).

\section{The antennal lobe}

OSN axons group along the antenna, forming the dorsal and ventral tracts of the antennal nerve (AN). Short before entering the brain, they form six distinct tracts (T1-6), four of which project directly into the antennal lobe (AL), the primary olfactory center of the insect brain. The two other tracts (T5-6) bypass the AL to reach deeper regions of the brain, the dorsal lobe and the subesophageal zone (Pareto 1972). The AL is subdivided in 165 spheroidal units called glomeruli. Each glomerulus receives the input from all the OSNs carrying the same OR (together with Orco) and coming from all parts of the antenna (Dahanukar et al. 2005). Hence, the 165 different glomeruli of the worker AL represent the whole diversity of honeybee ORs as a topological map. The neural representation of odors at the level of the AL has been well described in workers using in vivo optical imaging (Joerges et al. 1997; Galizia et al. 1999b; Sachse et al. 1999). Olfactory stimuli, such as complex mixtures of odorants or individual volatiles, all elicit activity from several glomeruli, forming a combinatorial activity pattern. Concerning individual odorants, olfactory coding depends mainly on the chemical features, for instance, the chemical functional group or chain length of the molecule (Sachse et al. 1999; Carcaud et al. 2012, 2018).

A strong sexual dimorphism is observed at the central level, with clear specificities in the ALs of the reproductive castes compared with the workers (Fig. 3). Even though drones' antennal nerve is thicker than that of workers (Streinzer et al. 2013), their AL presents a much lower number of glomeruli (103-110 depending on the studies), four of which are conspicuously hypertrophied (Arnold et al. 1985; Brockmann and Brückner 1999, 2001; Nishino et al. 2009; Bastin et al. 2018). These malespecific enlarged glomeruli were coined macroglomeruli (MGs), as they are reminiscent of similar structures found in male moths, which form the macroglomerular complex (Hansson et al. 1991; Todd et al. 1995). In these insects, MGs are involved in the detection and processing of female pheromone components (Hildebrand 1996; Hansson and Anton 2000). The drone MGs were thus proposed to play a similar role and to serve the detection and processing of mating-related odorants. This hypothesis was confirmed for one of the drone macroglomeruli, MG2, by showing that it responds specifically to 9-ODA and does not respond to floral compounds or other honeybee pheromonal compounds (Sandoz 2006). This finding was compatible with the idea of a highly specific and dedicated pathway, i.e., a "labeled-line," for the detection and processing of 9-ODA 
in the bee brain, with OSNs carrying AmOR11 projecting to MG2. The same calcium imaging study did not detect any significant response in the other optically accessible macroglomerulus, MG1, to other queen mandibular components, social pheromones, or floral odors (Sandoz 2006). MG3 and MG4 are located in regions of the AL that could not be accessed with optical recordings and as for MG1, their function remains unknown.

The organization of the queen AL is generally similar to that of the workers, but it contains about 10 glomeruli less $(\sim 155-162$ in queens vs. 165-171 in workers; Fig. 3), and its volume is slightly lower $(\sim 15 \%)$ (Arnold et al. 1988; Groh et al. 2006; Groh and Rössler 2008). In addition, one glomerulus seems conspicuously enlarged in the queen ( 3-4 times) compared with its counterpart (glomerulus T1-44) in the worker (Arnold et al. 1988). Note that this particular glomerulus is already extremely large in workers (Flanagan and Mercer 1989; Galizia et al. 1999a) and its size was shown to be plastic in workers, varying for instance with foraging experience (Brown et al. 2002, 2004). Its larger size, as well as its similar position in the AL as MG1, MG2, and MG3 of the drone, led to the hypothesis that this MG may be involved in the recognition of pheromones (Arnold et al. 1988; Groh et al. 2006; Groh and Rössler 2008). This observation is interesting in the light of recent experiments detailed above showing that sexually mature virgin queens are attracted to drone-volatiles (Bastin et al. 2017a). Note, however, that other functions may be attributed to this enlarged glomerulus, as for instance, a role in queen fighting when several queens emerge in the same colony (Pflugfelder and Koeniger 2003), or in their egg laying choices, which depend on colony status (Amiri et al. 2020).

\section{Projections to higher-order centers}

AL glomeruli are also innervated by local inhibitory interneurons (LNs) which connect glomeruli and process the olfactory signal, and the dendrites of projections neurons (PNs) which convey processed olfactory information toward higher-order centers, the mushroom bodies (MB) and the lateral horn (LH) (Witthöft 1967; Flanagan and Mercer 1989; Sun et al. 1993; Galizia and Kimmerle 2004). In bees, PN axons are divided in 5 different antennal lobe tracts: two principal tracts, the medial antennal lobe tract (m-ALT) and the lateral antennal lobe tract (l-ALT), and three smaller tracts called mediolateral tracts (ml-ALT) (Mobbs 1982; Abel et al. 2001; Carcaud et al. 2012; Rössler and Brill 2013). For both m-ALT and l-ALT, each PN's dendrite originates within a single glomerulus. These neurons are thus categorized as uniglomerular projections neurons (uPNs). This means that information from a single glomerulus, i.e., OSN input from a single OR (and modulated by LN input from other glomeruli) is transmitted to higher-order centers. Each PN type collects information from two independent subsets of AL glomeruli, so that m-ALT and l-ALT may be envisaged as forming two different olfactory subsystems. In addition, they project to essentially different regions of the LH and the MB, in opposite order (Kirschner et al. 2006) (Fig. 3). In honeybee workers, extensive work has been dedicated to discover the possible functional differences existing between these two pathways. Shortly, differences in odor specificity, response latency, concentration dependency, and coincident activity have been reported (Müller et al. 2002; Krofczik et al. 2009; Yamagata et al. 2009; Brill et al. 2015). In terms of odor quality coding, a general redundancy of their odor response spectra was observed in the different studies, with specificities however regarding odorants chemical features: while the l-ALT primarily conveyed information about odorants' chain length, the m-ALT conveyed more information about odorants' functional group (Carcaud et al. 2012, 2018). Nevertheless, the most remarkable difference between both tracts was the fact that queen pheromones were only processed by the l-ALT while brood pheromones were mainly processed by the m-ALT (Carcaud et al. 2015). Components of social pheromones like the aggregation and the alarm pheromone were processed by both subsystems. Such studies are missing in drones and queens. We know however that the drone AL displays about 50 glomeruli less than the worker AL. A recent study showed that most of these missing glomeruli correspond to the T3 tract of OSNs entering the AL and may be related to the absence of S. basiconica in the drone (Kropf et al. 2014), i.e., a reduction in the input region of the m-ALT. As a result, in drones, a total of 45 glomeruli convey information towards higher-order brain centers via the m-ALT, including the macroglomerulus, MG4. The other 64 glomeruli use the 1-ALT, and they include 3 macroglomeruli, MG1, MG2 and MG3 (Kropf et al. 2014). It is interesting to note that in both workers and drones, l-ALT is the tract responding to queen pheromonal compounds. On the other hand, the workers' part of the m-ALT that specifically responds to brood pheromone may correspond to the missing glomeruli in the drone. Given its location, information from the queen MG is expected to project to higher-order centers via the l-ALT.

\section{Higher-order centers}

Little is known about the higher-order centers in drones and queens, and we will present here speculative ideas and our current working model. The LH is thought to be an integration center involved in the triggering of innate responses to odors (Strutz et al. 2014; Dolan et al. 2019). Neuroanatomical as well as functional studies in Drosophila suggested that PN projections to the LH are 
stereotyped and that different LH subregions encode the biological nature of olfactory stimuli, with differing locations for food vs pheromone information or positive vs negative hedonic values (Jefferis et al. 2007; Strutz et al. 2014). Therefore, the LH seems a likely structure where projections from sex pheromone-responding MGs could trigger mating behavioral routines. In moths, male-specific m-ALT PNs are reported to terminate in a particular area of the lateral horn, which is distinct from that targeted by plant odor PNs (Zhao et al. 2014). Likewise, we expect to find MG-specific projections in the drone LH. In honeybee workers, in vivo calcium imaging indeed found odor-specific activity patterns at the level of 1-ALT PN terminals in the LH, which differentiated QMP components, including 9-ODA, from other pheromone types (Roussel et al. 2014). A similar organization in drones could explain how MG activation could trigger mating behavior routines.

The MBs are known to be a multisensory integration structure and are sites of memory formation and olfactory-based decision-making (Hammer and Menzel 1998; Zars 2000; Davis 2005; Szyszka et al. 2005). Within the MBs, PNs project onto densely packed intrinsic neurons, the Kenyon cells (KCs), in the calyx (lip and basal ring), where they form microglomerular complexes (Groh and Rössler 2020). Sexual dimorphism is relatively small between drone and worker MBs, with 150,000 cells in the male MB (-12\%) compared with 170,000 in workers (Witthöft 1967). Odor representation at the $\mathrm{KC}$ level is highly sparse and each $\mathrm{KC}$ represents a particular pattern of PN inputs. One may thus find there the continuation of labeled lines from the MGs, with KCs that could be highly specific to, for instance, 9-ODA, or the drone pheromone. Also, as PN inputs to $\mathrm{KCs}$ are strongly intermingled with many different PNs converging on a single $\mathrm{KC}$, MG olfactory information may become contextualized with other olfactory cues, like the co-occurrence of the drone-pheromone with the queensignal 9-ODA or with other environmental odorants. Furthermore, the MBs are multimodal sensory centers of the insect brain, which offers further contextualization of the MG message. Drone mating behavior is a highly multimodal sensory experience. As detailed above, visual and olfactory cues play major roles in finding the congregations and following the queen, but other sensory modalities may also be involved. The magnetic sense (Loper 1985), proprioception from the flight muscles, and/or mechanosensory perception of air displacement (wind, wing beats) by the Johnston's organ (Ai et al. 2007) could act in synergy with visual and olfactory cues. Multisensory integration of olfactory stimuli with other modalities could take place at the level of MB output neurons (MBONs) (Rybak and Menzel 1993).
Such neurons have been shown to integrate for instance visual and olfactory information (Filla and Menzel 2015; Strube-Bloss and Rössler 2018). While some MBONs act as recurrent neurons toward MB input regions (calyx), others project to the lateral protocerebrum and the $\mathrm{LH}$ region (Rybak and Menzel 1993, 1998), allowing learned (MB) and innate (LH) information to be integrated into a behavioral decision. Similarly, we propose that pheromone information from the queen and/or other drones could be interpreted in the context of other sensory modalities in the MB and that MBONs would transmit to the $\mathrm{LH}$ a contextual, multisensory signal. Integration between processed inputs from the MB to the LH would allow fine tuning of bees' mating behavior depending on contextual cues. Neurons leaving the LH and descending pathways involved in behavioral output are still unknown in honeybees. Recent data in Drosophila confirm that different types of LH output neurons can trigger different locomotor programs (Dolan et al. 2019). A similar organization can be expected in bees.

\section{Neural circuit evolution across honeybee species}

Although the Western honeybee A. mellifera has been mostly studied with regard to the neurobiology of olfactory coding, the genus Apis contains nine recognized eusocial honeybee species and possibly 5 others awaiting confirmation (Ruttner 1988; Oldroyd and Wongsiri 2009; Hepburn and Radloff 2011; Koeniger et al. 2014; Smith 2020). Honeybees are classically divided in three groups: the dwarf honeybees (e.g., A. florea), the giant honeybees (e.g., A. dorsata), and the cavity-nesting honeybees (e.g., A. mellifera, A. cerana, A. koschevnikovi). These species differ according to a range of characters like size, nest construction, complexity of the waggle dance, and division of labor or foraging behavior (Ruttner 1988; Arias and Sheppard 2005; Raffiudin and Crozier 2006; Koeniger et al. 2011). However, Apis species share the same mating behavior, with the formation of drone congregations and queen mating with multiple drones within these congregations (see above) (Koeniger and Koeniger 2000; Baer 2005; Hepburn and Radloff 2011; Koeniger et al. 2014). In Southeast Asia, several of these species live in sympatry and reproductive isolation seems to be maintained by a number of pre- and post-zygotic barriers, including different daily mating periods and locations, different genitalia shapes, incompatibilities for sperm storage and fertilization, etc. (Koeniger and Koeniger 2000; Oldroyd and Wongsiri 2009; Koeniger et al. 2011). As the role played by olfactory sex communication in this reproductive isolation was unclear, we recently compared the anatomy of the antennal lobe in five of these species (Bastin et al. 2018). Apart from differences in absolute numbers of glomeruli in the drone $\mathrm{AL}$, 


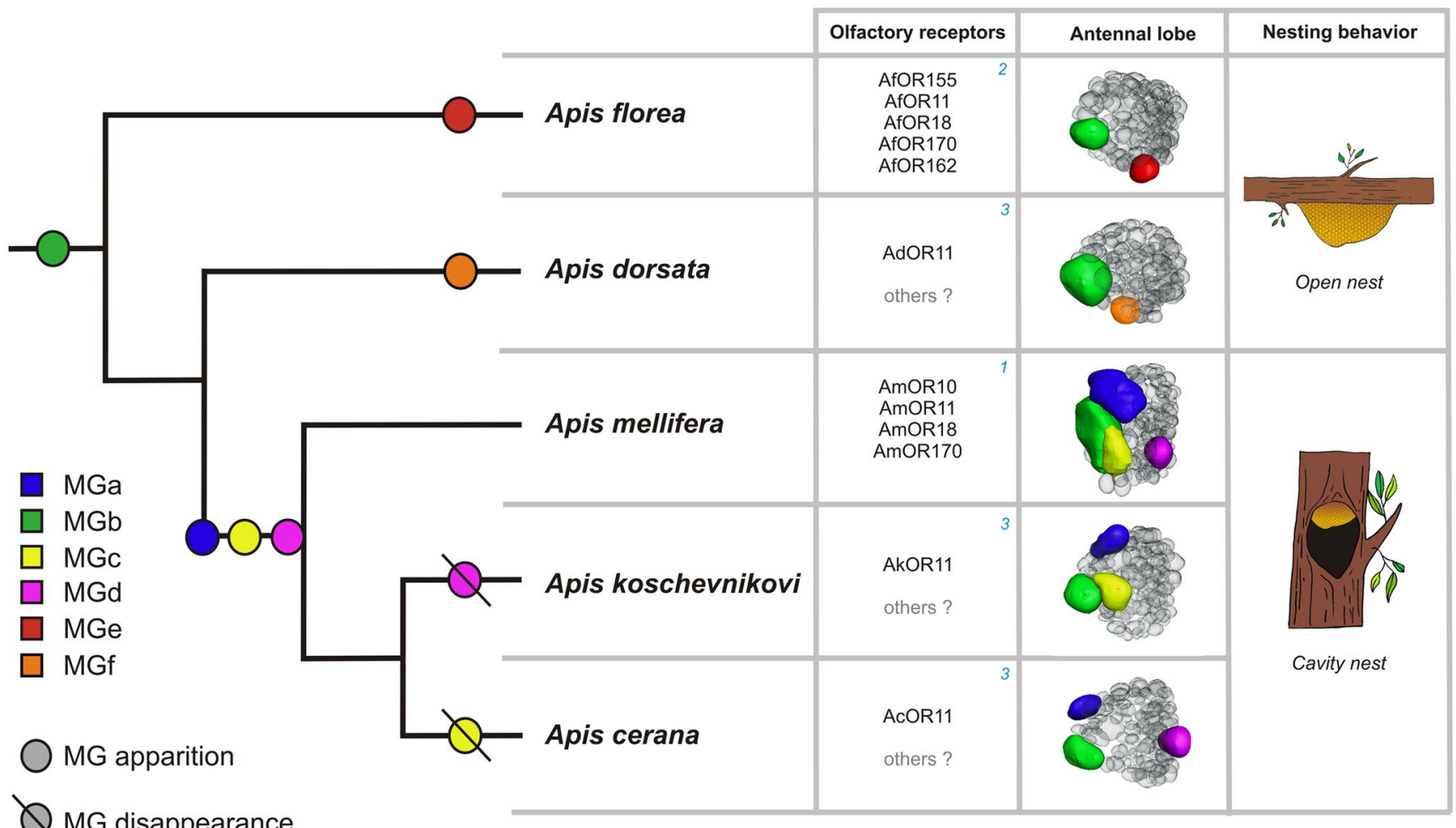

Fig. 4 Putative model of drone antennal lobe evolution in the Apis genus. The equipment of each species in macroglomeruli ( $\mathrm{MGa}$ to $\mathrm{MGe}$ ) in the drone antennal lobe is mapped onto the established phylogeny of honeybee species. The presence of MGb (corresponding to MG2 in A. mellifera) in all evaluated species suggests its existence in their last common ancestor, possibly with a common function in the detection of queen pheromone. Honeybee evolution was accompanied by an increase in the number of macroglomeruli in cavity-nesting bees compared with open-nesting bees. A possible model of MG evolu-

we observed a remarkable diversity in $\mathrm{MG}$ equipment in the different Apis species, with some conserved and some speciesunique units (Fig. 4) (Bastin et al. 2018). MGs are usually numbered within species depending on their position on a ventrodorsal axis ( 1 to the most ventral, $n$ to the most dorsal) (Arnold et al. 1985; Brockmann and Brückner 2001; Wanner et al. 2007; Nishino et al. 2009). Such a numbering system was not applicable across species, so we used a different naming system using letters, from MGa to MGf, in such a way that the same letter refers to putatively homologous macroglomeruli across species. In this system, the macroglomeruli described above for Apis mellifera drones are identified as MGa to MGd. Strikingly, one macroglomerulus MGb (MG2 in Apis mellifera) was consistently present at the same location, showing the highest volume and exhibiting the same dense innervation by the T1 olfactory tract in all investigated species. Supposedly, MGb was present in their last common ancestor, which lived about ten million years ago (Garnery et al. 1991; Arias and Sheppard 2005; Raffiudin and Crozier 2006), supporting the idea that it played an enduring and crucial role in their tion is presented with possible MG gains and losses (modified from Bastin et al. (2018)). 3D models of left antennal lobes are represented in a rostral view as this view best represents relative positions in all Apis species. Olfactory receptors potentially playing a role in drone mating behavior are indicated, with the relevant reference: 1, Wanner et al. (2007); Jain and Brockmann (2020); 2, Karpe et al. (2016); 3, by extension from observations of the presence of 9-ODA in these species' QMP, as well as the presence of MGb, we propose a role for the orthologs of AmOR11 in these species

reproduction. Interestingly, 9-ODA is produced by the queens of all these species and is known to attract the drones from all Apis species tested until now (Gary 1962; Butler et al. 1967; Shearer et al. 1970; Sannasi and Rajulu 1971; Koeniger and Koeniger 2000; Nagaraja and Brockmann 2009). In addition, recent sequencing of other honeybee genomes confirmed that Asian species possess an ortholog of AmOR11 (at least A. cerana, A. florea, and A. dorsata) (Karpe et al. 2016; Liu et al. 2019). In A. florea, afOR11 is strongly overexpressed in the drone antenna compared with that of workers (Karpe et al. 2016). From the data in A. mellifera, we infer that the drones of all Apis species probably possess a labelled-line circuit involving OSNs expressing OR11 orthologs, which would feed into MGb, as a neural unit for processing 9-ODA information. Interestingly, the relative investment in MGb varied greatly across species (7 to $25 \%$ ), with Apis mellifera displaying the highest investment of all species. This extraordinary investment in MGb (MG2) is mirrored by the strongly increased number of placode sensilla/ OSNs at the periphery compared with other species (Esslen and Kaissling 1976; Brockmann and Brückner 2005) and the 
high sensitivity of the A. mellifera drone antenna to 9-ODA (Brockmann et al. 1998). This may have given this species the ability to detect the queen pheromone (here 9-ODA) from longer distances than other species (Brockmann and Brückner 2005). Besides MGb, our study identified five macroglomeruli over all species (MGa to MGf), with a varied equipment across species, from 2 to 4 macroglomeruli (Fig. 4). This may suggest different levels of complexity across species in the communication channels involved in mating. What may be the function of these additional macroglomeruli? Since mating behavior is highly similar across Apis species, we consider that the same cues as for $A$. mellifera may be involved: additional queen pheromone compounds and/or drone-related olfactory cues. Interestingly, queens' mandibular glands produce multiple compounds, and the ratios of individual components in the queen pheromonal blend clearly differ among species (Slessor et al. 1988; Plettner et al. 1997; Keeling et al. 2000, 2001). For instance, in addition to 9-ODA 10-hydroxy-(E)-2-decenoic acid (10-HDA) is present in the queen pheromone of all Apis species studied (Slessor et al. 1988; Plettner et al. 1997; Keeling et al. 2000). However, this compound is synthesized in larger quantities by $A$. florea queens and induces strong attraction in A. florea males (Plettner et al. 1997; Keeling et al. 2000; Nagaraja and Brockmann 2009). Thus 10-HDA may be processed by the second A. florea MG. A complexification of the queen pheromonal blend seems to have occurred in the group of extant cavity-nesting species (Slessor et al. 1988; Plettner et al. 1997). Accordingly, we found more macroglomeruli in these species (A. cerana, A. koschevnikovi, and $A$. mellifera) compared with both open-air-nesting species (A. dorsata and A. florea). As mentioned above, such additional stimuli may play a role supporting reproductive isolation in the context of sympatry.

\section{Conclusion and future avenues}

As we have described, our knowledge about molecules and circuits involved in honeybee mating behavior is still fragmentary and several research avenues may be proposed to help us progress in the future.

First, at the level of olfactory receptors, AmOR10, AmOR18, and AmOR170 were consistently found to be overexpressed in the drone antenna. They are therefore our best candidate receptors for the OSNs that project to the macroglomeruli MG1, MG3, and MG4. Heterologous expression of these ORs in Xenopus oocytes did not allow previous authors to determine their ligands and apparently, the ORs are not activated by compounds of the QMP (Wanner et al. 2007). As we described above, the processing of 9-ODA by a possible AmOR11-MG2 labeled line allows to explain how drones can follow the queen within the congregation, and it is still unclear if other queen signals may have been selected to play an additional role in honeybee mating behavior, for instance, at shorter range than 9-ODA. Some behavioral studies suggested that other queen components may increase drone attraction to queen at short range (Brockmann et al. 2006) or even act as an aphrodisiac (Renner and Vierling 1977). In addition, 9-ODA cannot explain how the drones form and find the congregations in the first place. Drone attraction towards drone-emitted volatiles seems now established, and a substantial number of clues point to the existence of a drone pheromone, potentially acting in a similar manner as the worker aggregation pheromone (Lensky et al. 1985; Free 1987; Brandstaetter et al. 2014; Bastin et al. 2017a, 2017b; Villar et al. 2017). We can thus speculate that the three orphan ORs, and the respective MGs, could be activated by additional queen components and/or a drone pheromone. We are therefore looking for possibly three additional labeled lines in the drone olfactory system.

Three experimental systems are available for progressing in the discovery of these labeled lines. First, heterologous expression of ORs seems a promising avenue. This can be done in a range of heterologous systems, including Xenopus oocytes (Wanner et al. 2007), insect cell lines (Claudianos et al. 2014), or the Drosophila empty neuron system (Montagne et al. 2012). The second promising approach would be the recording of MGC neurons using electrophysiology, either intracellular recordings followed by ontophoretic stainings (Abel et al. 2001) or even-MGs being large structures-extracellular recordings with microwires (Strube-Bloss and Rössler 2018). The third experimental system is in vivo calcium imaging, which allows measuring activity in the antennal lobe. Due to the diverse locations of the MGs in this structure, some of which are difficult to access, one will have to resort to advanced brain preparations, for instance, from the ventral side (Carcaud et al. 2012, 2018) or to advanced recording techniques like two-photon microscopy, although to this day, this technique has not allowed to image very far from the brain surface (Paoli et al. 2018; Baracchi et al. 2020). Independently of the recording technique used, a large screening of queen and drone gland extracts and volatiles will be necessary to try and find the missing pheromones.

If putative ligands for the drone-biased ORs and/or volatiles that activate the MGs are found, it will then be important to evaluate the possible behavioral roles of these putative pheromones. In a lab context, the possible attraction of drone and/or virgin queen to such compound can be tested on tethered individuals running on a treadmill (Brandstaetter et al. 2014; Bastin et al. 2017a, 2017b). In a natural setting, it is possible to provide these compounds as baits on drone flyways (Villar et al. 2017) or to perform choice tests at or near drone congregation areas (Renner and Vierling 1977; Brockmann et al. 2006). With respect 
to drone pheromones, the potential to use such compounds to stabilize or favor the presence of drone congregations, for instance, near apiaries, offers interesting beekeeping applications to this research.

The work on the ALs of the different Apis species suggests an enrichment of sex pheromone communication through evolution in these species, with more numerous MGs in cavity-nesting species, like A. mellifera. Like A. mellifera, an increasing number of honeybee genomes are being sequenced and annotated, with their OR repertoire determined (Karpe et al. 2016). By following the strategy above, identification of the co-attractants in sex communication of these sometimes sympatric species will be accessible. Relating differences in OR/MG equipement with the ecologies and evolutionary histories of these species will be extremely stimulating. We form the wish that the next years will offer new breakthroughs in our understanding of the pheromones, neurons, and circuits underlying honeybees' fascinating mating behavior.

Acknowledgments We would like to thank the members of the EVOLBEE team and the Evolution and Behavior department of EGCE for insightful discussions.

Funding This work received support from the French Research Ministery to J. Mariette and the ANR (ANR-17-CE20-003 to J.C.S.).

\section{Compliance with ethical standards}

Conflict of interest The authors declare that there is no conflict of interest.

\section{References}

Abel R, Rybak J, Menzel R (2001) Structure and response patterns of olfactory interneurons in the honeybee, Apis mellifera. J Comp Neurol 437:363-383

Ai H, Nishino H, Itoh T (2007) Topographic organization of sensory afferents of Johnston's organ in the honeybee brain. J Comp Neurol 502(6):1030-1046

Amiri E, Le K, Melendez CV, Strand MK, Tarpy DR, Rueppell O (2020) Egg-size plasticity in Apis mellifera: honey bee queens alter egg size in response to both genetic and environmental factors. J Evol Biol 33(4):534-543

Arias MC, Sheppard WS (2005) Phylogenetic relationships of honey bees (Hymenoptera:Apinae:Apini) inferred from nuclear and mitochondrial DNA sequence data. Mol Phylogenet Evol 37:25-35

Arnold G, Budharugsa S, Masson C (1988) Organization of the antennal lobe in the queen honey bee, Apis mellifera $\mathrm{L}$ (Hymenoptera:Apidae). Int J Insect Morphol Embryol 17:185-195

Arnold G, Masson C, Budharugsa S (1985) Comparative study of the antennal lobes and their afferent pathway in the worker bee and the drone (Apis mellifera). Cell Tissue Res 242:593-605

Baer B (2005) Sexual selection in Apis bees. Apidologie 36:187-200

Baracchi D, Cabirol A, Devaud JM, Haase A, d'Ettorre P, Giurfa M (2020) Pheromone components affect motivation and induce persistent modulation of associative learning and memory in honey bees. Commun Biol 3:447
Barbier M, Lederer E (1960) Structure chimique de la substance royale de la reine d'abeille Apis mellifera L. CR Acad Sci Paris 251:1131-1135

Bastin F, Cholé H, Lafon G, Sandoz JC (2017) Virgin queen attraction toward males in honey bees. Sci Rep 7:6293

Bastin F, Couto A, Larcher V, Phiancharoen M, Koeniger G, Koeniger N, Sandoz JC (2018) Marked interspecific differences in the neuroanatomy of the male olfactory system of honey bees (genus Apis). J Comp Neurol 526:3020-3034

Bastin F, Savarit F, Lafon G, Sandoz JC (2017) Age-specific olfactory attraction between Western honey bee drones (Apis mellifera) and its chemical basis. PLoS ONE 12:e0185949

Baudry E, Solignac M, Garnery L, Gries M, Cornuet J, Koeniger N (1998) Relatedness among honeybees (Apis mellifera) of a drone congregation. Proc Roy Soc B 265:2009-2014

Benton R, Sachse S, Michnick SW, Vosshall LB (2006) Atypical membrane topology and heteromeric function of Drosophila odorant receptors in vivo. PLoS Biol 4:e20

Berg BG, Zhao XC, Wang G (2014) Processing of pheromone information in related species of heliothine moths. Insects 5:742-761

Blum M, Boch R, Doolittle R, Tribble M, Traynham J (1971) Honey bee sex attractant: conformational analysis, structural specificity, and lack of masking activity of congeners. J Insect Physiol 17:349-364

Boch R, Shearer DA, Young JC (1975) Honey bee pheromones: field tests of natural and artificial queen substance. J Chem Ecol 1:133-148

Brandstaetter AS, Bastin F, Sandoz JC (2014) Honeybee drones are attracted by groups of consexuals in a walking simulator. J Exp Biol 217:1278-1285

Brill MF, Meyer A, Rössler W (2015) It takes two - coincidence coding within the dual olfactory pathway of the honeybee. Front Physiol 6:208

Brill MF, Rosenbaum T, Reus I, Kleineidam CJ, Nawrot MP, Rössler W (2013) Parallel processing via a dual olfactory pathway in the honeybee. J Neurosci 33:2443-2456

Brockmann A, Brückner D (1999) Dimorphic antennal systems in gynandromorphic honey bees, Apis mellifera L. (Hymenoptera:Apidae). Int J Insect Morphol Embryo 28:53-60

Brockmann A, Brückner D (2001) Structural differences in the drone olfactory system of two phylogenetically distant Apis species, A. florea and A. mellifera. Naturwiss 88:78-81

Brockmann A, Brückner D (2005) Drone antennae and the evolution of sex-pheromone communication in honeybees. Indian Bee J 65:131-138

Brockmann A, Brückner D, Crewe RM (1998) The EAG response spectra of workers and drones to queen honeybee mandibular gland components: the evolution of a social signal. Naturwiss $85: 283-285$

Brockmann A, Dietz D, Spaethe J, Tautz J (2006) Beyond 9-ODA: sex pheromone communication in the European honey bee Apis mellifera L. J Chem Ecol 32:657-667

Brown SM, Napper RM, Mercer AR (2004) Foraging experience, glomerulus volume, and synapse number: A stereological study of the honey bee antennal lobe. J Neurobiol 60:40-50

Brown SM, Napper RM, Thompson CM, Mercer AR (2002) Stereological analysis reveals striking differences in the structural plasticity of two readily identifiable glomeruli in the antennal lobes of the adult worker honeybee. J Neurosci 22:8514-8522

Butenandt A, Beckmann R, Stamm D, Hecker E (1959) Über den Sexual-Lockstoff des Seidenspinners Bombyx mori. Reindarstellung und Konstitution Z Naturforsch B 14:283-284

Butler C, Calam D, Callow R (1967) Attraction of Apis mellifera drones by the odours of the queens of two other species of honeybees. Nature 213:423-424

Butler CG, Callow RK, Johnston NC (1959) Extraction and purification of "queen substance" from queen bees. Nature 184:1871-1871 
Butler CG, Callow RK, Johnston NC (1962) The isolation and synthesis of queen substance, 9-oxodec-trans-2-enoic acid, a honeybee pheromone. Proc Roy Soc London B 155:417-432

Butler CG, Fairey EM (1964) Pheromones of the honeybee: biological studies of the mandibular gland secretion of the queen. J Api Res 3:65-76

Butterwick JA, Del Marmol J, Kim KH, Kahlson MA, Rogow JA, Walz T, Ruta V (2018) Cryo-EM structure of the insect olfactory receptor Orco. Nature 560:447-452

Carcaud J, Giurfa M, Sandoz JC (2015) Differential combinatorial coding of pheromones in two olfactory subsystems of the honey bee brain. J Neurosci 35:4157-4167

Carcaud J, Giurfa M, Sandoz JC (2018) Differential processing by two olfactory subsystems in the honeybee brain. Neurosci 374:33-48

Carcaud J, Hill T, Giurfa M, Sandoz JC (2012) Differential coding by two olfactory subsystems in the honeybee brain. J Neurophysiol 108:1106-1121

Claudianos C, Lim J, Young M, Yan S, Cristino AS, Newcomb RD, Reinhard J (2014) Odor memories regulate olfactory receptor expression in the sensory periphery. Eur J Neurosci 39:1642-1654

Currie RW (1987) The biology and behaviour of drones. Bee World 68(3):129-143

Dade H (1977) Anatomy and physiology of the honeybee. International Bee Research Association.

Dahanukar A, Hallem EA, Carlson JR (2005) Insect chemoreception. Cur Opin Neurobiol 15:423-430

Danty E, Arnold G, Huet JC, Huet D, Masson C, Pernollet JC (1998) Separation, characterization and sexual heterogeneity of multiple putative odorant-binding proteins in the honeybee Apis mellifera L. (Hymenoptera:Apidea). Chem Senses 23:83-91

Danty E, Briand L, Michard-Vanhee C, Perez V, Arnold G, Gaudemer O, Pernollet JC (1999) Cloning and expression of a queen pheromone-binding protein in the honeybee: an olfactoryspecific, developmentally regulated protein. J Neurosci 19:7468-7475

Danty E, Michard-Vanhee C, Huet JC, Genecque E, Pernollet JC, Masson C (1997) Biochemical characterization, molecular cloning and localization of a putative odorant-binding protein in the honey bee Apis mellifera L. (Hymenoptera:Apidea). FEBS Lett 414:595-598

Davis RL (2005) Olfactory memory formation in drosophila: from molecular to systems neuroscience. Ann Rev Neurosci 28:275-302

Dolan M J, Frechter S, Bates A S, Dan C, Huoviala P, Roberts R J, Jefferis GS (2019) Neurogenetic dissection of the Drosophila lateral horn reveals major outputs, diverse behavioural functions, and interactions with the mushroom body. Elife 8:e43079 https ://doi.org/10.7554/eLife.43079

Esslen J, Kaissling KE (1976) Zahl und Verteilung antennaler Sensillen bei der Honigbiene (Apis mellifera L.). Zoomorphol 83:227-251

Estoup A, Solignac M, Cornuet JM (1994) Precise assessment of the number of patrilines and of genetic relatedness in honeybee colonies. Proc Roy Soc B 258:1-7

Fang Y, Song F, Zhang L, Aleku DW, Han B, Feng M, Li J (2012). Differential antennal proteome comparison of adult honeybee drone, worker and queen (Apis mellifera L.) J Proteomics 75:756-773

Farina WM, Grüter C, Acosta L, Mc Cabe S (2007) Honeybees learn floral odors while receiving nectar from foragers within the hive. Naturwiss 94:55-60

Filla I, Menzel R (2015) Mushroom body extrinsic neurons in the honeybee (Apis mellifera) brain integrate context and cue values upon attentional stimulus selection. J Neurophysiol 114:2005-2014
Flanagan D, Mercer AR (1989) An atlas and 3-D reconstruction of the antennal lobes in the worker honey bee, Apis mellifera L (Hymenoptera: Apidae). Int J Insect Morphol Embryol 18:145-159

Foret S, Maleszka R (2006) Function and evolution of a gene family encoding odorant binding-like proteins in a social insect, the honey bee (Apis mellifera). Genome Res 16(11):1404-1413

Free JB (1987) Pheromones of social bees. Chapman \& Hall, London

Free JB, Williams IH (1975) Factors determining the rearing and rejection of drones by the honeybee colony. Anim Behav 23:650-675

Galizia CG, Kimmerle B (2004) Physiological and morphological characterization of honeybee olfactory neurons combining electrophysiology, calcium imaging and confocal microscopy. J Comp Physiol A 190:21-38

Galizia CG, McIlwrath SL, Menzel R (1999) A digital threedimensional atlas of the honeybee antennal lobe based on optical sections acquired by confocal microscopy. Cell Tissue Res 295:383-394

Galizia CG, Menzel R (2000) Odour perception in honeybees: coding information in glomerular patterns. Cur Opin Neurobiol 10:504-510

Galizia CG, Menzel R (2001) The role of glomeruli in the neural representation of odours: results from optical recording studies. J Insect Physiol 47:115-129

Galizia CG, Sachse S, Rappert A, Menzel R (1999) The Glomerular code for odor representation is species specific in the honeybee Apis mellifera. Nature Neurosci 2:473-478

Garnery L, Vautrin D, Cornuet JM, Solignac M (1991) Phylogenetic relationships in the genus Apis inferred from mitochondrial DNA sequence data. Apidologie 22:87-92

Gary NE (1962) Chemical mating attractants in the queen honey bee. Science 136(3518):773-774

Gerig L (1972) Ein weiterer Duftstoff zur Anlockung der Drohnen von Apis mellifica (L). Z Angewandte Entomol 70:286-289

Getz WM, Akers RP (1993) Olfactory response characteristics and tuning structure of placodes in the honey bee Apis mellifera $\mathrm{L}$. Apidologie 24:195-217

Giurfa M (2007) Behavioral and neural analysis of associative learning in the honeybee: a taste from the magic well. J Comp Physiol A 193:801-824

Giurfa M, Sandoz JC (2012) Invertebrate learning and memory: fifty years of olfactory conditioning of the proboscis extension response in honeybees. Learn Mem 19:54-66

Gries M, Koeniger N (1996) Straight forward to the queen: pursuing honeybee drones (Apis mellifera $\mathrm{L}$ ) adjust their body axis to the direction of the queen. J Comp Physiol A 179:539-544

Groh C, Ahrens D, Rössler W (2006) Environment-and age-dependent plasticity of synaptic complexes in the mushroom bodies of honeybee queens. Brain Behav Evol 68:1-14

Groh C, Rössler W (2008) Caste-specific postembryonic development of primary and secondary olfactory centers in the female honeybee brain. Arthropod Struct Dev 37:459-468

Groh C, Rössler W (2020) Analysis of synaptic microcircuits in the mushroom bodies of the honeybee. Insects 11:43

Guerrieri F, Schubert M, Sandoz JC, Giurfa M (2005) Perceptual and neural olfactory similarity in honeybees. PLoS Biol 3:e60

Hammer M, Menzel R (1998) Multiple sites of associative odor learning as revealed by local brain microinjections of octopamine in honeybees. Learn Mem 5:146-156

Hansson BS, Anton S (2000) Function and morphology of the antennal lobe: new developments. Annu Rev Entomol 45:203-231

Hansson BS, Christensen TA, Hildebrand JG (1991) Functionally distinct subdivisions of the macroglomerular complex in the antennal lobe of the male sphinx moth Manduca sexta. J Comp Neurol 312:264-278 
Hansson BS, Stensmyr MC (2011) Evolution of insect olfaction. Neuron 72:698-711

Hepburn HR, Radloff SE (2011) Biogeography of the dwarf honeybees, Apis andreniformis and Apis florea. Apidologie 42:293-300

Hildebrand JG (1996) Olfactory control of behavior in moths: central processing of odor information and the functional significance of olfactory glomeruli. J Comp Physiol A 178:5-19

Howell DE, Usinger RL (1933) Observations on the flight and length of life of drone bees. Ann Entomol Soc America 26:239-246

Jain R, Brockmann A (2020) Sex-specific molecular specialization and activity rhythm-dependent gene expression in honey bee antennae. J Exp Biol 223:12

Jefferis GS, Potter CJ, Chan AM, Marin EC, Rohlfing T, Maurer CR Jr, Luo L (2007) Comprehensive maps of Drosophila higher olfactory centers: spatially segregated fruit and pheromone representation. Cell 128:1187-1203

Jernigan CM, Halby R, Gerkin RC, Sinakevitch I, Locatelli F, Smith BH (2020) Experience-dependent tuning of early olfactory processing in the adult honey bee, Apis mellifera. J Exp Biol 223:1-13

Joerges J, Küttner A, Galizia CG, Menzel R (1997) Representations of odours and odour mixtures visualized in the honeybee brain. Nature 387:285-288

Jones JC, Myerscough MR, Graham S, Oldroyd BP (2004) Honey bee nest thermoregulation: diversity promotes stability. Science 305(5682):402-404

Junca P, Garnery L, Sandoz JC (2019) Genotypic trade-off between appetitive and aversive capacities in honeybees. Sci Rep 9(1):10313

Kaissling KE, Renner M (1968) Antennale Rezeptoren für Queen Substance und Sterzelduft bei der Honigbiene. Z Vgl Physiol 59:357-361

Kaissling KE (1987) RH Wright lectures on insect olfaction. Simon Fraser University, Burnaby, British Columbia, Canada

Karpe SD, Jain R, Brockmann A, Sowdhamini R (2016) Identification of complete repertoire of apis florea odorant receptors reveals complex orthologous relationships with Apis mellifera. Genome Biol Evol 8:2879-2895

Keeling CI, Otis GW, Hadisoesilo S, Slessor KN (2001) Mandibular gland component analysis in the head extracts of Apis cerana and Apis nigrocincta. Apidologie 32:243-252

Keeling CI, Slessor KN, Koeniger N, Koeniger G, Punchihewa RWK (2000) Quantitative analysis of the mandibular gland components of the dwarf honey bee (Apis florea Fabricius). Apidologie 31:293-299

Kirschner S, Kleineidam CJ, Zube C, Rybak J, Grünewald B, Rössler W (2006) Dual olfactory pathway in the honeybee, Apis mellifera. J Comp Neurol 499:933-952

Koeniger G, Koeniger N, Ellis J, Connor L J (2014) Mating biology of honey bees (Apis mellifera). Wicwas Press LLC

Koeniger G, Koeniger N, Phiancharoen M (2011) Comparative reproductive biology of honeybees, in Honeybees of Asia. Springer, pp 159-206

Koeniger N, Koeniger G (2000) Reproductive isolation among species of the genus Apis. Apidologie 31:313-339

Koeniger N, Koeniger G (2004) Mating behavior in honey bees (genus Apis). Trop Agri Res Extension 7:13-28

Koeniger N, Koeniger G, Gries M, Tingek S (2005) Drone competition at drone congregation areas in four Apis species. Apidologie 36:211-221

Krofczik S, Menzel R, Nawrot MP (2009) Rapid odor processing in the honeybee antennal lobe network. Front Comput Neurosci 2:9

Kropf J, Kelber C, Bieringer K, Rössler W (2014) Olfactory subsystems in the honeybee: sensory supply and sex specificity. Cell Tissue Res 357:583-595
Kropf J, Rössler W (2018) In-situ recording of ionic currents in projection neurons and Kenyon cells in the olfactory pathway of the honeybee. PLoS ONE 13(1):e0191425

Lacher V (1964) Elektrophysiologische Untersuchungen an einzelnen Rezeptoren für Geruch, Kohlendioxyd, Luftfeuchtigkeit und Temperatur auf den Antennen der Arbeitsbiene und der Drohne (Apis mellifica $\mathrm{L}$ ). Z verg1 Physiol 48:587-623

Larsson MC, Domingos AI, Jones WD, Chiappe ME, Amrein H, Vosshall LB (2004) Or83b encodes a broadly expressed odorant receptor essential for Drosophila olfaction. Neuron 43:703-714

Laska M, Galizia CG, Giurfa M, Menzel R (1999) Olfactory discrimination ability and odor structure-activity relationships in honeybees. Chem Senses 24:429-438

Lensky Y, Cassier P, Notkin M, Delormejoulie C, Levinsohn M (1985) Pheromonal activity and fine-structure of the mandibular glands of honeybee drones (Apis mellifera L) (Insecta, Hymenoptera, Apidae). J Insect Physiol 31:265

Liu JF, Yang L, Li M, He XJ, Wang ZL, Zeng ZJ (2019) Cloning and expression pattern of odorant receptor 11 in Asian honeybee drones, Apis cerana (Hymenoptera, Apidae). J Asia-Pacific Entomol 22:110-116

Loper GM (1985) Influence of age on the fluctuation of iron in the œnocytes of honey bee (Apis mellifera) drones. Apidologie $16: 181-184$

Loper GM (1992) What do we really know about drone flight behaviour? Bee World 73:198-203

Loper GM, Wolf WW, Taylor Jr OR (1992) Honey bee drone flyways and congregation areas: radar observations. J Kansas Entomol Soc $223-230$

Maleszka R (2018) Beyond Royalactin and a master inducer explanation of phenotypic plasticity in honey bees. Commun Biol 1:8

Masson C, Mustaparta H (1990) Chemical information processing in the olfactory system of insects. Physiol Rev 70:199-245

Masson C, Pham-Delègue M, Fonta C, Gascuel J, Arnold G, Nicolas G, Kerszberg M (1993) Recent advances in the concept of adaptation to natural odour signals in the honeybee, Apis mellifera L. Apidologie 24:169-194

Menzel R (2012) The honeybee as a model for understanding the basis of cognition. Nat Rev Neurosci 13:758-768

Michener CD (1974) The social behavior of the bees: a comparative study. Harvard University Press

Missbach C, Dweck HKM, Vogel H, Vilcinskas A, Stensmyr MC, Hansson BS, Grosse-Wilde E (2014) Evolution of insect olfactory receptors. Elife 3:e02115

Mobbs PG (1982) The brain of the honeybee Apis mellifera L. The connections and spatial organization of the mushroom bodies. Phil Transactions Roy Soc B 298:309-354

Montagne N, Chertemps T, Brigaud I, Francois A, Francois MC, de Fouchier A, Jacquin-Joly E (2012) Functional characterization of a sex pheromone receptor in the pest moth Spodoptera littoralis by heterologous expression in Drosophila. Eur J Neurosci 36:2588-2596

Müller DM, Abel RA, Brandt RB, Zöckler MZ, Menzel R (2002) Differential parallel processing of olfactory information in the honeybee, Apis mellifera L. J Comp Physiol A 188:359-370

Nagaraja N, Brockmann A (2009) Drones of the dwarf honey bee Apis florea are attracted to (2E)-9-oxodecenoic acid and (2E)-10hydroxydecenoic acid. J Chem Ecol 35:653-655

Nishino H, Nishikawa M, Mizunami M, Yokohari F (2009) Functional and topographic segregation of glomeruli revealed by local staining of antennal sensory neurons in the honeybee Apis mellifera. J Comp Neurol 515:161-180 
Nouvian M, Hotier L, Claudianos C, Giurfa M, Reinhard J (2015) Appetitive floral odours prevent aggression in honeybees. Nat Commun 6:10247

Ohtani T, Fukuda H (1977) Factors governing the spatial distribution of adult drone honeybees in the hive. J Apicultural Res 16:14-26

Oldroyd BP, Wongsiri S (2009) Asian honey bees: biology, conservation, and human interactions. Harvard University Press

Page RE Jr, Peng CYS (2001) Aging and development in social insects with emphasis on the honey bee, Apis mellifera L. Exp Gerontol 36:695-711

Pain J, Roger B (1978) Rythme circadien des acides ceto- 9 decène-2 oique, pheromone de la reine, et hydroxy-10 decene- 2 oique des ouvrieres d'abeilles Apis mellifica ligustica S. Apidologie 9:263-272

Pankiw T, Winston ML, Plettner E, Slessor KN, Pettis JS, Taylor OR (1996) Mandibular gland components of European and Africanized honey bee queens (Apis mellifera L). J Chem Ecol 22(4):605-615

Paoli M, Albi A, Zanon M, Zanini D, Antolini R, Haase A (2018) Neuronal response latencies encode first odor identity information across subjects. J Neurosci 38(43):9240-9251

Pareto A (1972) Die zentrale Verteilung der Fühlerafferenz bei Arbeiterinnen der Honigbiene, Apis mellifera L. Z Zellforsch 131:109-140

Pesenti ME, Spinelli S, Bezirard V, Briand L, Pernollet J-C, Tegoni M, Cambillau C (2008) Structural basis of the honey bee PBP pheromone and $\mathrm{pH}$-induced conformational change. J Mol Biol 380(1): 158-169

Pflugfelder J, Koeniger N (2003) Fight between virgin queens (Apis mellifera) is initiated by contact to the dorsal abdominal surface. Apidologie 34(3):249-256

Plettner E, Otis GW, Wimalaratne PDC, Winston ML, Slessor KN, Pankiw T, Punchihewa PWK (1997) Species- and castedetermined mandibular gland signals in honeybees (Apis). J Chem Ecol 23(2):363-377

Raffiudin R, Crozier RH (2006) Phylogenetic analysis of honey bee behavioral evolution. Mol Phylogenet Evol 43(2):543-552

Rangel J, Seeley T (2012) Colony fissioning in honey bees: size and significance of the swarm fraction. Insectes Soc 59(4):453-462

Renner M, Vierling G (1977) Die Rolle des Taschendrüsenpheromons beim Hochzeitsflug der Bienenkönigin. Behav Ecol Sociobiol 2(3):329-338

Rhodes J, Lacey M (2007) Changes with age in queen honey bee (Apis mellifera) head chemical constituents (Hymenoptera:Apidae). Sociobiol 50:11-22

Ribbands CR (1953) The behaviour and social life of honeybees. Bee Research Association, London

Robertson HM, Wanner KW (2006) The chemoreceptor superfamily in the honey bee, Apis mellifera: expansion of the odorant, but not gustatory, receptor family. Genome Res 16(11):1395-1403

Rössler W, Brill MF (2013) Parallel processing in the honeybee olfactory pathway: structure, function, and evolution. J Comp Physiol A 199(11):981-996

Roussel E, Carcaud J, Combe M, Giurfa M, Sandoz JC (2014) Olfactory coding in the honeybee lateral horn. Curr Biol 24(5):561-567

Rueppell O, Fondrk MK, Page RE (2005) Biodemographic analysis of male honey bee mortality. Aging Cell 4(1):13-19

Ruttner F (1966) The life and flight activity of drones. Bee World 47(3):93-100

Ruttner F (1985) Reproductive behaviour in honeybees. Fortschritte der Zoologie 31:225-236

Ruttner F (1988) Biogeography and taxonomy of honeybees. Springer, Berlin

Ruttner F, Ruttner H (1965) Untersuchungen über die Flugaktivität und das Paarungsverhalten der Drohnen. II Beobachtungen an Drohnensammelplätzen Z Bienenforsch 8:1-9
Ruttner F, Ruttner H (1966) Untersuchungen über die Flugaktivität und das Paarungsverhalten der Drohnen. III. Flugweite und Flugrichtung der Drohnen. Z Bienenforsch 8:332-354

Ruttner F, Ruttner H (1968) Untersuchungen über die Flugaktivität und das Paarungsverhalten der Drohnen. IV. Zur Fernorientierung und Ortsstetigkeit der Drohnen auf ihren Paarungsflügen. Z Bienenforsch 9:259-268

Ruttner H, Ruttner F (1972) Investigations on the flight activity and the mating behaviour of drones. V. Drone congregation areas and mating distance. Apidologie 3:203-232

Rybak J, Menzel R (1993) Anatomy of the mushroom bodies in the honey bee brain: the neuronal connections of the alpha-lobe. $\mathrm{J}$ Comp Neurol 334:444-465

Rybak J, Menzel R (1998) integrative properties of the Pe1 neuron, a unique mushroom body output neuron. Learn Mem 5:133-145

Sachse S, Rappert A, Galizia CG (1999) The spatial representation of chemical structures in the antennal lobe of honeybees: steps towards the olfactory code. Eur J Neurosci 11:3970-3982

Sakurai T, Namiki S, Kanzaki R (2014) Molecular and neural mechanisms of sex pheromone reception and processing in the silkmoth Bombyx mori. Front Physiol 5:125

Sandoz JC (2006) Odour-evoked responses to queen pheromone components and to plant odours using optical imaging in the antennal lobe of the honey bee drone Apis mellifera L. J Exp Biol 209(18):3587-3598

Sandoz JC (2011) Behavioral and neurophysiological study of olfactory perception and learning in honeybees. Front Syst Neurosci 5:98

Sandoz JC, Deisig N, Brito Sanchez MG, Giurfa M (2007) Understanding the logics of pheromone processing in the honeybee brain: from labeled-lines to across-fiber patterns. Front Behav Neurosci 1:5

Sannasi A, Rajulu GS (1971) 9-oxodec-trans-2-enoic acid in the Indian honeybees. Life Sci 10:195-201

Sato K, Pellegrino M, Nakagawa T, Nakagawa T, Vosshall LB, Touhara K (2008) Insect olfactory receptors are heteromeric ligand-gated ion channels. Nature 452:1002-1006

Schlüns H, Moritz RF, Neumann P, Kryger P, Koeniger G (2005) Multiple nuptial flights, sperm transfer and the evolution of extreme polyandry in honeybee queens. Anim Behav 70:125-131

Schneider D, Steinbrecht RA (1968) Checklist of insect olfactory sensilla. Symposia Zool Soc London 23:279-297

Seeley TD (1995) The wisdom of the hive: the social physiology of honey bee colonies. Harvard University Press

Shearer DA, Boch R, Morse RA, Laigo FM (1970) Occurrence of 9-oxodec-trans-2-enoic acid in queens of Apis dorsata, Apis cerana, and Apis mellifera. J Insect Physiol 16:1437-1441

Simpson J (1958) The factors which cause colonies of Apis mellifera to swarm. Insectes Soc 5:77-95

Skirkeviciene Z, Skirkevicius A (1994) Worker bee and drone (Apis mellifera $\mathrm{L}$ ) behavior and functional reorganization of their olfactory receptors. Pheromones 4:83-92

Sladen F (1901) A scent organ in the bee. British Bee Journal 29:1513-1521

Sladen F (1902) A scent producing organ in the abdomen of the worker of Apis mellifera. Entomologists Monthly Magazine 38:208-211

Slessor KN, Kaminski LA, King GGS, Borden JH, Winston ML (1988) Semiochemical basis of the retinue response to queen honey bees. Nature 332:354-356

Slessor KN, Winston ML, Le Conte Y (2005) Pheromone communication in the honeybee (Apis mellifera $\mathrm{L}$ ). J Chem Ecol 31:2731-2745

Slifer EH, Sekhon SS (1961) Fine structure of the sense organs on the antennal flagellum of the honey bee, Apis mellifera Linnaeus. J Morphology 109:351-381 
Smith DR (2020) Biogeography of honey bees. In: Starr C. (Ed.) Encyclopedia of social insects. Springer 14 p.

Smith ML, Ostwald MM, Seeley TD (2015) Adaptive tuning of an extended phenotype: honeybees seasonally shift their honey storage to optimize male production. Anim Behav 103:29-33

Snodgrass RE (1956) Anatomy of the honey bee. Cornell University Press, Ithaca, New York

Strauss K, Scharpenberg H, Crewe RM, Glahn F, Foth H, Moritz RFA (2008) The role of the queen mandibular gland pheromone in honeybees (Apis mellifera): honest signal or suppressive agent? Behav Ecol Sociobiol 62:1523-1531

Streinzer M, Kelber C, Pfabigan S, Kleineidam CJ, Spaethe J (2013) Sexual dimorphism in the olfactory system of a solitary and a eusocial bee species. J Comp Neurol 521:2742-2755

Strube-Bloss MF, Nawrot MP, Menzel R (2016) Neural correlates of side-specific odour memory in mushroom body output neurons. Proc Royal Soc B 283(1844):20161270

Strube-Bloss MF, Rössler W (2018) Multimodal integration and stimulus categorization in putative mushroom body output neurons of the honeybee. Royal Society Open Science 5(2): 171785

Strutz A, Soelter J, Baschwitz A, Farhan A, Grabe V, Rybak J, Sachse S (2014) Decoding odor quality and intensity in the Drosophila brain. Elife 3:e04147

Sun XJ, Fonta C, Masson C (1993) Odour quality processing by bee antennal lobe interneurones. Chem Senses 18:355-377

Szyszka P, Ditzen M, Galkin A, Galizia CG, Menzel R (2005) Sparsening and temporal sharpening of olfactory representations in the honeybee mushroom bodies. J Neurophysiol 94:3303-3313

Todd JL, Anton S, Hansson BS, Baker TC (1995) Functional organization of the macroglomerular complex related to behaviourally expressed olfactory redundancy in male cabbage looper moths. Wiley Online Library 20:349-361

Vareschi E (1971) Duftunterscheidung bei der Honigbiene Einzelzell-Ableitungen und Verhaltensreaktionen. Z Vgl Physiol 75:143-173

Vetter RS, Visscher PK (1997) Influence of age on antennal response of male honey bees, Apis mellifera, to queen mandibular pheromone and alarm pheromone component. J Chem Ecol 23:1867-1880

Vieira FG, Rozas J (2011) Comparative genomics of the odorantbinding and chemosensory protein gene families across the Arthropoda: origin and evolutionary history of the chemosensory system. Genome Biol Evol 3:476-490

Vierling G, Renner M (1977) Die Bedeutung des Sekretes der Tergittaschendrüsen für die Attraktivität der Bienenkönigin gegenüber jungen Arbeiterinnen. Behav Ecol Sociobiol 2:185-200

Villar G, Baker TC, Patch HM, Grozinger CM (2015) Neurophysiological mechanisms underlying sex- and maturationrelated variation in pheromone responses in honey bees (Apis mellifera). J Comp Physiol A 201:731-739
Villar G, Hefetz A, Grozinger CM (2019) Evaluating the effect of honey bee (Apis mellifera) queen reproductive state on pheromone-mediated interactions with male drone bees. J Chem Ecol 45:588-597

Villar G, Wolfson MD, Hefetz A, Grozinger CM (2017) Evaluating the role of drone-produced chemical signals in mediating social interactions in honey bees (Apis mellifera). $\mathrm{J}$ Chem Ecol 44:1-8

Vogt RG (2003) Biochemical diversity of odor detection: OBPs, ODEs and SNMPs. In: Blomquist G, Vogt R (eds) Insect pheromone biochemistry and molecular biology. Academic Press, San Diego, pp 391-445

Wanner KW, Nichols AS, Walden KK, Brockmann A, Luetje CW, Robertson HM (2007) A honey bee odorant receptor for the queen substance 9-oxo-2-decenoic acid. Proc Natl Acad Sci USA 104:14383-14388

Weaver N (1966) Physiology of caste determination. Annu Rev Entomol 11:79-102

Wicher D, Schafer R, Bauernfeind R, Stensmyr MC, Heller R, Heinemann SH, Hansson BS (2008) Drosophila odorant receptors are both ligand-gated and cyclic-nucleotide-activated cation channels. Nature 452:1007-1011

Winston ML (1987) The biology of the honey bee. Harvard University Press, Cambridge, Massachussetts

Witherell PC (1971) Duration of flight and of interflight time of drone honey bees, Apis mellifera. Ann Entomol Soc America 64:609-612

Witthöft W (1967) Absolute Anzahl und Verteilung der Zellen im Hirn der Honigbiene. Z Morphologie Tiere 61:160-184

Woyke J (1955) Multiple mating of the honeybee queen (Apis mellifica L) in one nuptial flight. Bull Acad Polon Sci Cl 3:175-180

Xiao S, Sun JS, Carlson JR (2019) Robust olfactory responses in the absence of odorant binding proteins. Elife 8:e51040

Xu P, Atkinson R, Jones DNM, Smith DP (2005) Drosophila OBP LUSH is required for activity of pheromone-sensitive neurons. Neuron 45:193-200

Yamagata N, Schmuker M, Szyszka P, Mizunami M, Menzel R (2009) Differential odor processing in two olfactory pathways in the honeybee. Front Syst Neurosci 3:16

Zars T (2000) Behavioral functions of the insect mushroom bodies. Cur Opin Neurobiol 10:790-795

Zayed A, Robinson GE (2012) Understanding the relationship between brain gene expression and social behavior: lessons from the honey bee. Annu Rev Genet 46:591-615

Zhao XC, Kvello P, Lofaldli BB, Lillevoll SC, Mustaparta H, Berg BG (2014) Representation of pheromones, interspecific signals, and plant odors in higher olfactory centers; mapping physiologically identified antennal-lobe projection neurons in the male heliothine moth. Front Syst Neurosci 8:186

Publisher's Note Springer Nature remains neutral with regard to jurisdictional claims in published maps and institutional affiliations. 